\title{
Evaluation of proximal femoral nail-antirotation and cemented, bipolar hemiarthroplasty with calcar replacement in treatment of intertrochanteric femoral fractures in terms of mortality and morbidity ratios
}

\author{
Intertrokanterik femur kırıklarının tedavisinde proksimal femoral çivi-antirotasyonun ve \\ çimentolu kalkar destekli bipolar hemiartroplastinin \\ mortalite ve morbidite oranları açısından değerlendirilmesi
}

\author{
Erdinç Esen, MD., Hakan Dur, MD., M. Baybars Ataoğlu, MD., Tacettin Ayanoğlu, MD., Sacit Turanlı, MD. \\ Department of Orthopedics and Traumatology, Medical Faculty of Gazi University, Ankara, Turkey
}

\begin{abstract}
Objectives: This study aims to assess the mortality and morbidity rates of patients with intertrochanteric femoral fractures who were performed proximal femoral nail-antirotation (PFNA) or cemented, bipolar hemiarthroplasty with calcar replacement.

Patients and methods: A total of 127 patients (42 males, 85 females; mean age 79.2 years; range 55 to 98 years) who were treated due to proximal femoral fracture between January 2008 and January 2011 were compared retrospectively in terms of intraoperative mortality, total mortality, and monthly distribution of mortality rates. Of these 127 patients, 92 ( 28 males, 64 females; mean age 80.24 years; range 55 to 94 years) who were alive, who achieved at least a 12-month follow-up, and could walk and fulfil daily activities in preoperative period were included in the study. Patients were divided into two groups as PFNA group $(\mathrm{n}=34)$ and cemented, bipolar hemiarthroplasty with calcar replacement group (hemiarthroplasty group; $n=58$ ). Both groups were compared in terms of duration of operation, requirement for intraoperative blood transfusion, duration of hospital stay, functional outcomes, quality of life, complication and revision rates, and costs of operation.
\end{abstract}

Results: Patients in both groups had the same type of fracture. Bone mineral densitometry results and the type and risk of anesthesia of both groups were similar. No significant difference was detected between two groups in terms of intraoperative mortality, total mortality, and monthly distribution of mortality rates $(\mathrm{p}>0.05)$. Mean durations of operation were 54.85 minutes (range 40-110 minutes) and 74.66 minutes (range 55-120 minutes) in the PFNA and hemiarthroplasty groups, respectively. Mean durations of hospital stay were 5.91 days (range 5-12 days) and 9.41 days (range 6-16 days) in the PFNA and hemiarthroplasty groups, respectively. In the PFNA group, durations of operation and hospital stay were shorter and functional results were superior $(\mathrm{p}<0.05)$. Requirement for blood transfusion was lower in the PFNA group.

Conclusion: Both PFNA and cemented, bipolar hemiarthroplasty with calcar replacement are good techniques in treatment of intertrochanteric femoral fractures. Internal fixation may be more appropriate for elderly patients due to shorter duration of operation and lower risk of reoperation. Keywords: Hemiarthroplasty; hip fracture; intertrochanteric femur fracture; proximal femoral nail-antirotation.

\section{ÖZ}

Amaç: Bu çalışmada proksimal femoral çivi-antirotasyon (PFNA) veya çimentolu, kalkar destekli, bipolar hemiartroplasti uygulanan intertrokanterik femur kırıklı hastaların mortalite ve morbidite oranları değerlendirildi.

Hastalar ve yöntemler: Proksimal femur kırığı nedeniyle Ocak 2008 Ocak 2011 tarihleri arasında tedavi gören 127 hasta (42 erkek, 85 kadın; ort. yaş 79.2 yıl; dağılım 55-98 yıl) ameliyat sırasında mortalite, toplam mortalite ve mortalite oranlarının aylara göre dağılımı açısından retrospektif olarak karşılaştırıldı. Bu 127 hastadan yaşayan, en az 12 aylık takibe ulaşan, ameliyat öncesi dönemde yürüyebilen ve günlük aktivitelerini yerine getirebilen 92 hasta (28 erkek, 64 kadın; ort. yaş 80.24 yıl; dağılım 55-94 yıl) çalışmaya dahil edildi. Hastalar PFNA grubu $(\mathrm{n}=34)$ ve çimentolu, kalkar destekli, bipolar hemiartroplasti grubu (hemiartroplasti grubu; $n=58$ ) olmak üzere iki gruba ayrıldı. Her iki grup ameliyat süresi, ameliyat sırasında kan transfüzyonu ihtiyacı, hastanede yatış süresi, fonksiyonel sonuçlar, yaşam kalitesi, komplikasyon ve revizyon oranları ve ameliyat maliyetleri açısından karşılaştırıldı.

Bulgular: Her iki gruptaki hastalarda aynı kırık tipi vardı. İki grubun kemik mineral yoğunluğu sonuçları, anestezi tipi ve riski benzerdi. İki grup arasında ameliyat sırasında mortalite, toplam mortalite ve mortalite oranlarının aylara göre dağılımı açısından anlamlı farklılık saptanmadı $(\mathrm{p}>0.05)$. Ortalama ameliyat süresi PFNA ve hemiartroplasti gruplarında sırasıyla 54.84 dakika (dağ 1 lım 40-110 dakika) ve 74.66 dakika (dağılım 55-120 dakika) idi. Ortalama hastanede yatış süresi PFNA ve hemiartroplasti gruplarında sırasıyla 5.91 gün (dağılım 5-12 gün) ve 9.41 gün (dağılım 6-16 gün) idi. Proksimal femoral çivi-antirotasyon grubunda ameliyat süresi ve hastanede yatış süresi daha kısa; fonksiyonel sonuçlar daha iyi idi $(\mathrm{p}<0.05)$. Kan transfüzyonu ihtiyacı PFNA grubunda daha az idi.

Sonuç: İntertrokanterik femur kırıklarının tedavisinde hem PFNA hem çimentolu, kalkar destekli, bipolar hemiartroplasti iyi tekniklerdir. Yaşlı hastalarda ameliyat süresinin daha kısa ve tekrar ameliyat riskinin düşük olması nedeniyle internal tespit daha uygun olabilir.

Anahtar sözcükler: Hemiartroplasti; kalça kırığı; intertrokanterik femur kırığı; proksimal femoral çivi-antirotasyon.

- Received: September 09, 2016 Accepted: January 04, 2017

- Correspondence: Erdinç Esen, MD. Gazi Üniversitesi Tıp Fakültesi Ortopedi ve Travmatoloji Anabilim Dalı, 06500 Beşevler, Ankara, Turkey. Tel: +90 532 - 3656502 e-mail: erdincesen@gmail.com 
Intertrochanteric femoral fractures generally occur with simple trauma on the basis of osteoporosis in elderly patients. ${ }^{[1]}$ Treatment of intertrochanteric femoral fracture is planned by assessment of functional sufficiency -for before fracture-, life expectancy, mental health, and social life of the patient. Primary treatment methods of fractures of this zone are conservative treatment, internal and external fixation, and total or partial arthroplasty. ${ }^{[2,3]}$ The purpose of all of these treatment methods is to reduce any complications which may occur after fractures. It is important to obtain a stable fixation of the fracture that will allow early mobilization, restoring the function of the limb.

In this study, we aimed to assess the mortality and morbidity rates of patients with intertrochanteric femoral fractures who were performed proximal femoral nail-antirotation (PFNA) or cemented, bipolar hemiarthroplasty with calcar replacement.

\section{PATIENTS AND METHODS}

A total of 127 patients (42 males, 85 females; mean age 79.2 years; range 55 to 98 years) who were operated in Gazi University Faculty of Medicine between January 2008 and January 2011 because of femoral intertrochanteric fractures were assessed retrospectively. Of these patients, 92 (28 males, 64 females; mean age 80.24 years; range 55 to 94 years) who could walk and perform their daily work preoperatively, and who were followed-up for a minimum of 12 months were included. Of the 92 patients, $34(37 \%)$ were treated with PFNA (PFNA group), and 58 (63\%) with cemented, bipolar hemiarthroplasty with calcar replacement (hemiarthroplasty group). The mean follow-up
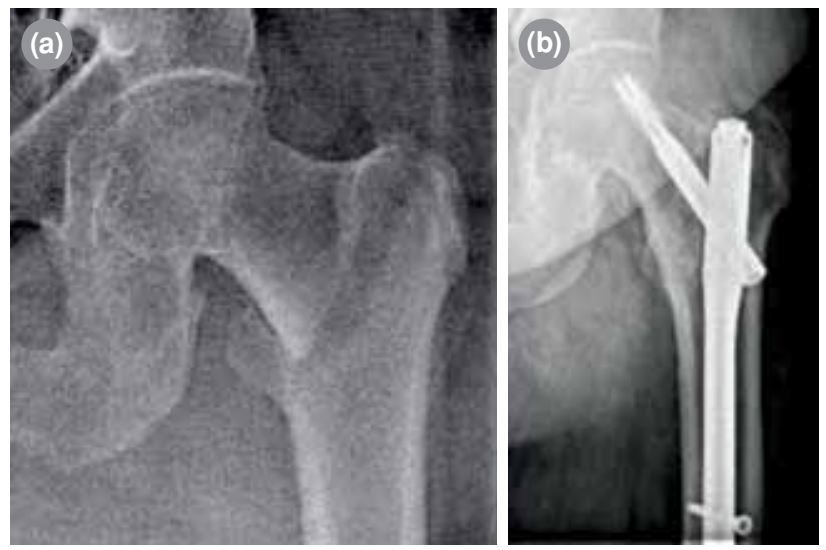

Figure 1. A 72-year-old female patient with left femur intertrochanteric fracture. She was treated with proximal femoral nail-antirotation. (a) Preoperative roentgenogram.

(b) Postoperative $24^{\text {th }}$ month roentgenogram. duration was 27.2 months (range 12-47 months). The study protocol was approved by the Gazi University Faculty of Medicine Ethics Committee. A written informed consent was obtained from each patient. The study was conducted in accordance with the principles of the Declaration of Helsinki.

At hospital admission; anterior-posterior radiographs, lateral radiographs of bilateral hip; anterior posterior hip radiographs in traction were taken to assess the fractures of trochanter minor and major. If there was no contraindication, all patients who were to undergo operation were administered low molecular weight heparin (according to their weight) for deep venous thrombosis prophylaxis. All patients were administered prophylactic first generation cephalosporin (according to their weight) 30 minutes preoperatively. Patients in PFNA group underwent operation after application of closed reduction with fluoroscopy on traction table, in supinated position (Figure 1). Patients in hemiarthroplasty group underwent operation in supinated or lateral decubitus position according to lateral or posterolateral approach (Figure 2). All patients were mobilized with a pair of crutches on full weight in first day postoperatively and started passive exercises on bed.

Patients in both groups were compared according to mortality rates, age, gender, mechanism and type of fracture, type of anesthesia, duration of operation, amount of intraoperative blood transfusion, duration of hospital stay, functional outcome of Harris hip score, data from Short Form 36 (SF-36), postoperative complications, revision rate, and cost of operation.
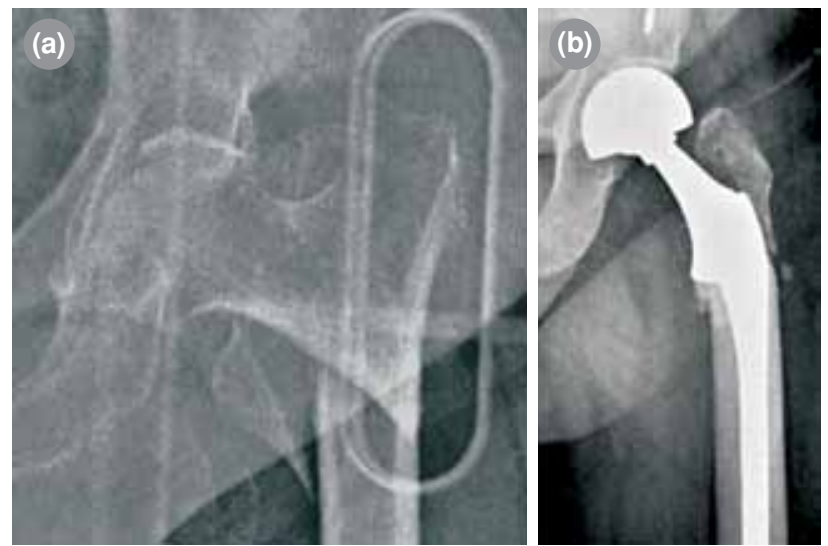

Figure 2. A 67-year-old female patient with left intertrochanteric fracture. She was treated with cemented, bipolar hemiarthroplasty with calcar replacement. (a) Preoperative roentgenogram. (b) Postoperative $24^{\text {th }}$ month roentgenogram. 
TABLE I

Preoperative data of patients

\begin{tabular}{|c|c|c|c|c|c|c|}
\hline & \multicolumn{3}{|c|}{ PFNA } & \multicolumn{3}{|c|}{ Hemiarthroplasty } \\
\hline & $\mathrm{n}$ & $\%$ & Mean & $\mathrm{n}$ & $\%$ & Mean \\
\hline Number of patients & 34 & & & 58 & & \\
\hline ASA score & & & 2.88 & & & 2.79 \\
\hline \multicolumn{7}{|c|}{ Fracture classification (OTA) } \\
\hline $\mathrm{A} 1$ & 4 & 11.7 & & 6 & 10.3 & \\
\hline $\mathrm{A} 2$ & 28 & 82.3 & & 49 & 84.4 & \\
\hline A3 & 2 & 6.2 & & 3 & 5.1 & \\
\hline
\end{tabular}

\section{Statistical analysis}

SPSS version 15.0 (SPSS Inc., Chicago, IL, USA) program was used to assess the data statistically. Statistics of percentage frequency were used for categorical data. Chi-square test was used for group comparisons. Also, means for data that were collected by measurement, standard deviation, minimummaximum statistics, and t-test for independent samples were used.

\section{RESULTS}

Eleven $(24.4 \%)$ of 34 patients in PFNA group and $24(29.3 \%)$ of 58 patients in hemiarthroplasty group died in one year. There was no significant difference between the groups according to total mortality rate and monthly distribution of mortality rates ( $p>0.05)$. Five patients died intraoperatively in hemiarthroplasty group, while none died intraoperatively in PFNA group. There was no significant difference between groups in terms of intraoperative death rates $(\mathrm{p}>0.05)$ (Table II).

Patients in both groups had the same fracture type (A2) according to Orthopaedic Trauma Association classification. Operations were performed by the same surgeon. There was no significant difference between groups according to type of fracture, bone mineral dansitometry, and risk and type of anesthesia $(p<0.05)$.
Mean durations of operation were 54.85 minutes (range 40-110 minutes) and 74.66 minutes (range 55-120 minutes) in the PFNA and hemiarthroplasty groups, respectively (Table II). There was a significant difference in durations of operation between PFNA and hemiarthroplasty groups $(\mathrm{p}<0.05)$, with duration of operation being shorter in PFNA group (Table II).

There was a significant difference in amount of intraoperative blood transfusion between the groups $(p<0.05)$, with PFNA group requiring lower amount of blood transfusion (Table II).

Mean durations of hospital stay were 5.91 days (range 5-12 days) and 9.41 days (range 6-16 days) in the PFNA and hemiarthroplasty groups, respectively. There was a significant difference in durations of hospital stay between the groups $(\mathrm{p}<0.05)$, with PFNA group staying in hospital for a shorter period of time (Table II).

Harris hip scores of patients were calculated by physical examination and anamnesis. Harris hip scores were 82.38 and 78.34 in PFNA and hemiarthroplasty groups, respectively. There was no significant difference between two groups ( $p>0.05)$ (Table III). According to the results of SF-36, there was no significant difference between the groups, with vitality/energy score being better in PFNA group $(p<0.05)$.

TABLE II

Treatment data of patients

\begin{tabular}{|c|c|c|c|c|c|c|}
\hline & \multicolumn{2}{|c|}{ PFNA } & \multicolumn{3}{|c|}{ Hemiarthroplasty } & \multirow[b]{2}{*}{$p$} \\
\hline & $\mathrm{n}$ & Mean & $\mathrm{n}$ & $\%$ & Mean & \\
\hline Duration of operation length (min) & & 54.8 & & & 74.6 & 0.00 \\
\hline Transfusion (units) & & 0.24 & & & 1.22 & 0.00 \\
\hline Duration of hospital stay (day) & & 5.91 & & & 9.41 & 0.00 \\
\hline Mortality during operation & 0 & & 5 & 8.6 & & 0.203 \\
\hline
\end{tabular}

PFNA: Proximal femoral nail-antirotation. 
TABLE III

Postoperative data of patients

\begin{tabular}{|c|c|c|c|c|c|c|c|c|c|}
\hline & \multicolumn{4}{|c|}{ PFNA } & \multicolumn{4}{|c|}{ Hemiarthroplasty } & \multirow[b]{2}{*}{$p$} \\
\hline & $\mathrm{n}$ & $\%$ & Mean & $\operatorname{cost}(\mathrm{TL})$ & $\mathrm{n}$ & $\%$ & Mean & cost $(\mathrm{TL})$ & \\
\hline Harris hip score & & & 82.3 & & & & 78.3 & & 0.09 \\
\hline Complications & 3 & 8.8 & & & 5 & 8.6 & & & 0.9 \\
\hline Revision operation & 0 & 0 & & & 4 & 6.8 & & & 0.104 \\
\hline Cost of operation & & & & 3,160 & & & & 2,862 & 0.00 \\
\hline Cost of operation (including revision) & & & & 3,160 & & & & 3,268 & 0.571 \\
\hline One-year mortality & 11 & 24.4 & & & 24 & 29.2 & & & 0.277 \\
\hline
\end{tabular}

PFNA: Proximal femoral nail-antirotation; TL: Turkish lira.

Regarding postoperative complications in PFNA group, two patients had superficial infection and one patient had minimal heterotopic ossification on the tip of trochanter major. None of the patients had nonunion, secondary varus deformity, or penetration of screw. In hemiarthroplasty group, two patients had deep infection, one patient had periprosthetic fracture, one patient had acetabular protrusion, and one patient had asymptomatic heterotopic ossification around great trochanter. There was no significant difference in frequency of complications between the groups ( $\mathrm{p}>0.05)$ (Table III).

In hemiarthroplasty group, four patients underwent revision operation compared to none in PFNA group. There was no significant difference in revision rates between the groups ( $p>0.05$ ) (Table III).

A comparison of costs of operation including both implant and hospital costs between the groups revealed that the cost of first operation was lower in hemiarthroplasty group. However, when we added the cost of revision operations, there was no significant difference between the groups ( $p>0.05)$ (Table III).

\section{DISCUSSION}

A great number of implant models have been developed for intertrochanteric fracture operation. In stable hip fractures, sliding nail maintains priority. ${ }^{[4]}$ Hemiarthroplasty is always a treatment choice in unstable intertrochanteric femoral fractures. ${ }^{[5]}$ Although hemiarthroplasty is a preferable alternative, intramedullary fixation techniques, which need less surgical cut, have been developed to protect patient's bone structure. Proximal femoral nail-antirotation is the internal fixation technique that causes minimum bone loss in femoral head and femoral neck. ${ }^{[6]}$ When compared to other intramedullary nails and screwplate techniques, intraoperative complication ratios and bleeding amount are lower. ${ }^{[7]}$
In our case series, mean durations of operation were 54.85 minutes (range 40-110 minutes) and 74.66 minutes (range 55-120 minutes) in the PFNA and hemiarthroplasty groups, respectively. The duration of operation in PFNA group was statistically significantly lower. Sancheti et al. ${ }^{[8]}$ reported a mean duration of operation of 71 minutes (range 55-88 minutes) in 37 patients who had unstable intertrochanteric fracture and who underwent hemiarthroplasty. Also, Haentjens et al. ${ }^{[9]}$ reported a mean duration of operation of 82 minutes in 37 patients who underwent bipolar hemiarthroplasty. Furthermore, Tang et al. ${ }^{[10]}$ compared the results of PFNA and hemiarthroplasty and reported mean durations of operation of 47.4 minutes and 76.2 minutes in PFNA and arthroplasty groups, respectively. Although duration of operation in PFNA group was statistically significantly lower in our study, which was compatible with other studies in the literature, we should remind that duration of operation depends on surgical experience and conditions of operation room.

In our study, a comparison of the amounts of intraoperative blood transfusion in PFNA and hemiarthroplasty groups revealed a significant difference. Patients in PFNA group required less transfusion compared to patients in hemiarthroplasty group (PFNA: mean 0.24 units, hemiarthroplasty: mean 1.22 units).

Moreover, in our patients, mean durations of hospital stay were 5.91 days (range 5-12 days) and 9.41 days (range 6-16 days) in the PFNA and hemiarthroplasty groups, respectively. In the literature, mean duration of hospital stay in hemiarthroplasty patients was reported as 12 days by Kayalı et al., ${ }^{[11]}$ while mean duration of hospital stay in PFNA patients was reported as 13.5 days by Sahin et al. ${ }^{[12]}$ and 5.3 days by Tang et al. ${ }^{[13]}$ 
In a study comparing PFNA and hemiarthroplasty, mean durations of hospital stay were 11 days and 14 days in PFNA and hemiarthroplasty patients, respectively. ${ }^{[10]}$ Mean duration of hospital stay in study groups was shorter than data from the literature. This situation may arise from different clinical conditions. However, the shorter duration of hospital stay in PFNA group may have been caused by less surgical incision leading to lower blood and electrolyte losses, and faster chance for replacement.

Harris hip scores were 82.8 and 78.34 in PFNA and hemiarthroplasty groups, respectively. Rodop et al. ${ }^{[14]}$ reported the results of 37 patients with unstable intertrochanteric femoral fractures, who underwent cemented, bipolar hemiarthroplasty, were followedup for 12 months, and $80 \%$ of whom obtained excellent and good results using the Harris hip-scoring system. Furthermore, in a study by Tang et al., ${ }^{[10]}$ Harris hip scores were 83 and 80.2 in PFNA and hemiarthroplasty groups, respectively, with no statistically significant difference between the groups.

In our study, we applied revision procedure to two patients with deep infection, one patient with periprosthetic fracture, and one patient with acetabular protrusion in hemiarthroplasty group. In PFNA group, revision was not needed. Although there was a significant difference in the occurrence of major complications, there was no significant difference in revision ratios between the groups. Studies in the literature have similar results in terms of major complications. ${ }^{[15]}$ In a study, Tang et al. ${ }^{[10]}$ reported that $22(14 \%)$ of hemiarthroplasty patients and $12(9.8 \%)$ of PFNA patients had complications, with no significant difference between the groups.

We also compared the cost of operation between our study groups. Conflicting results have been reported about the surgical treatment costs of proximal femoral fractures ${ }^{[16,17]}$ Although cost of first operation was lower in hemiarthroplasty group, there was no significant difference between the groups when we added the four patients who underwent revision operation in hemiarthroplasty group.

In our study, one-year mortality rates were similar with ratios of $24.4 \%$ and $29.3 \%$ in PFNA and hemiarthroplasty groups, respectively, with no significant difference between the groups. Mean age and comorbidities may affect mortality rates. However, these rates were similar in both groups. Although results in the literature are similar to our results, ${ }^{[18,19]}$ several publications reported a higher mortality rate in the arthroplasty group. ${ }^{[20]}$
There are several limitations to this study. The follow-up period was short because of the short life expectancy after fracture. Moreover, the study was designed retrospectively and the number of patients was low. Advantage of this study was all patients being treated by the same anesthesia method, same implants, and same surgeon.

In conclusion, our results show that both PFNA and cemented, bipolar hemiarthroplasty with calcar replacement are beneficial techniques in treatment of intertrochanteric femoral fractures. Internal fixation may be more appropriate for elderly patients with poor general conditions due to shorter duration of operation and lower risk of reoperation.

\section{Declaration of conflicting interests}

The authors declared no conflicts of interest with respect to the authorship and/or publication of this article.

\section{Funding}

The authors received no financial support for the research and/or authorship of this article.

\section{REFERENCES}

1. Atik OŞ. Has the awareness of orthopedic surgeons on osteoporosis been increased in the past decade? Eklem Hastalik Cerrahisi 2015;26:63.

2. Atik OŞ, Can FI, Şenol MS, Eren TK. Less invasive surgery using external fixator for the treatment of subtrochanteric femur fracture in a high-risk geriatric patient. Eklem Hastalik Cerrahisi 2016;27:100-2.

3. Anglen JO, Weinstein JN. Nail or plate fixation of intertrochanteric hip fractures: changing pattern of practice. A review of the American Board of Orthopaedic Surgery Database. J Bone Joint Surg [Am] 2008;90:700-7.

4. Görmeli G, Korkmaz MF, Görmeli CA, Adanaş C, Karataş T, Şimşek SA. Comparison of femur intertrochanteric fracture fixation with hemiarthroplasty and proximal femoral nail systems. Ulus Travma Acil Cerrahi Derg 2015;21:503-8.

5. Chan KC, Gill GS. Cemented hemiarthroplasties for elderly patients with intertrochanteric fractures. Clin Orthop Relat Res 2000;371:206-15.

6. PFNA: Leading the way to optimal stability: Synthes. Original instruments andimplants of the Association for the Study of Internal Fixation. AO/ASIF. Technique guide. Stratec Medica 2004;1-44.

7. Garg B, Marimuthu K, Kumar V, Malhotra R, Kotwal PP. Outcome of short proximal femoral nail antirotation and dynamic hip screw for fixation of unstable trochanteric fractures. A randomised prospective comparative trial. Hip Int 2011;21:531-6.

8. Sancheti Kh, Sancheti P, Shyam A, Patil S, Dhariwal Q, Joshi R. Primary hemiarthroplasty for unstable osteoporotic intertrochanteric fractures in the elderly: A retrospective case series. Indian J Orthop 2010;44:428-34.

9. Haentjens P, Casteleyn PP, De Boeck H, Handelberg F, Opdecam P. Treatment of unstable intertrochanteric and subtrochanteric fractures in elderly patients. Primary 
bipolar arthroplasty compared with internal fixation. J Bone Joint Surg [Am] 1989;71:1214-25.

10. Tang P, Hu F, Shen J, Zhang L, Zhang L. Proximal femoral nail antirotation versus hemiarthroplasty: a study for the treatment of intertrochanteric fractures. Injury 2012;43:876-81.

11. Kayali C, Agus H, Ozluk S, Sanli C. Treatment for unstable intertrochanteric fractures in elderly patients: internal fixation versus cone hemiarthroplasty. J Orthop Surg (Hong Kong) 2006;14:240-4.

12. Sahin S, Ertürer E, Oztürk I, Toker S, Seçkin F, Akman S. Radiographic and functional results of osteosynthesis using the proximal femoral nail antirotation (PFNA) in the treatment of unstable intertrochanteric femoral fractures. Acta Orthop Traumatol Turc 2010;44:127-34.

13. Tang X, Liu L, Yang TF, Tu CQ, Wang GL, Fang $Y$, et al. Preliminary effect of proximal femoral nail antirotation on emergency treatment of senile patients with intertrochanteric fracture. Chin J Traumatol 2010;13:212-6.

14. Rodop O, Kiral A, Kaplan H, Akmaz I. Primary bipolar hemiprosthesis for unstable intertrochanteric fractures. Int Orthop 2002;26:233-7.

15. Parker MJ, Handoll HH. Replacement arthroplasty versus internal fixation for extracapsular hip fractures in adults.
Cochrane Database Syst Rev 2006;2:000086.

16. Zielinski SM, Bouwmans CA, Heetveld MJ, Bhandari M, Patka P, Van Lieshout EM. The societal costs of femoral neck fracture patients treated with internal fixation.Osteoporos Int 2014;25:875-85.

17. Frihagen F, Waaler GM, Madsen JE, Nordsletten L, Aspaas $\mathrm{S}$, Aas E. The cost of hemiarthroplasty compared to that of internal fixation for femoral neck fractures. 2-year results involving 222 patients based on a randomized controlled trial. Acta Orthop 2010;81:446-52.

18. Johansson T, Jacobsson SA, Ivarsson I, Knutsson A, Wahlström O. Internal fixation versus total hip arthroplasty in the treatment of displaced femoral neck fractures: a prospective randomized study of 100 hips. Acta Orthop Scand 2000;71:597-602.

19. Rogmark C, Carlsson A, Johnell O, Sernbo I. A prospective randomised trial of internal fixation versus arthroplasty for displaced fractures of the neck of the femur. Functional outcome for 450 patients at two years. J Bone Joint Surg [Br] 2002;84:183-8.

20. Kapicioglu M, Ersen A, Saglam Y, Akgul T, Kizilkurt T, Yazicioglu O. Hip fractures in extremely old patients. J Orthop 2014;11:136-41. 